period of agriculture and the beginning of the application of scientific principles. The catalogue is excellently arranged for the use of students: an alphabetical list of English authors and translations is followed by a similar list of foreign authors and translations, and these latter are also catalogued. under the headings of their respective countries. This publication is invaluable not only for students of agricultural history and bibliography, but also for students of horticultural history, since there are numerous references to the early herbals and to treatises on gardening, particularly on the cultivation and propagation of fruit trees.

\section{Springtime the Safest Time}

UNDER this title the March issue of the Statistical Bulletin, which in spite of its austere title is remarkable for the sprightly character of its contents, illustrates the fact that life and limb are safer in the spring than at any other time of the year by the statement that, if all the year were April, the annual toll of fatal accidents in the United States would be 12,500 fewer than it has been in recent years. During the period 1934-37, the average number of deaths daily from accidents, particularly burns, falls and motor accidents in the United States was 285, whereas during the same years the daily average for April was 251, as compared with July, the worst month, when the average daily toll was 367 . The deaths in March and May averaged only a few more daily than in April. In conclusion, the writer recommends that the spring should be the season not only for cleaning the house and making necessary repairs, but also for clearing out "the junk of the mind-the complacency of fixed daily habits which are fraught with hazards".

\section{Earthquakes Registered at Hong-Kong}

DuRrNg January, twenty-two earthquakes were registered at the Royal Observatory, Hong-Kong, the greatest number on any one day being four on January 6. The greatest shock recorded was probably that of January 17 at 1 h. $21 \mathrm{~m}$. 25s. G.M.T., which exhibited a full complement of phases, and showed maximum amplitudes of $10.4 \mathrm{~mm}$. on the north-south component and $8.7 \mathrm{~mm}$. on the east-west component of the Milne-Shaw seismographs. The difference in arrival time of the primary and secondary waves for this earthquake was $5 \mathrm{~min} .17$ sec., which, according to Jeffreys' latest tables (Mon. Not. Roy. Astro. Soc., Geophysical Supplement, 1939, June), on the assumption of a normal depth of focus gives an epicentral distance of just over $33^{\circ}$ from Hong-Kong.

\section{Recent Earthquakes}

The United States Coast and Geodetic Survey in co-operation with Science Service and the Jesuit Seismological Association has determined the epicentres of the earthquakes of June 3 and 5. On the basis of reports from sixteen stations, the provisional epicentre of the earthquake of June 3 was lat. $25^{\circ} \mathrm{N}$., long. $110^{\circ} \mathrm{W}$., which is in the Gulf of California to the east of the island of San José. On the basis of reports from twenty seismological stations, the epicentre of the earthquake of June 5 was lat. $68^{\circ} \mathrm{N}$., long. $138^{\circ} \mathrm{W}$. This is in the Richardson range of mountains in the extreme north-west of Canada. Both areas are susceptible to earthquake shocks, having experienced them in the past, and both the earthquakes were comparatively large. The first was registered at Kew on June 3 at $18 \mathrm{~h} .17 \mathrm{~m} .43 \mathrm{~s}$. G.M.T., and the second on June 5 at $11 \mathrm{~h} .10 \mathrm{~m} .59 \mathrm{~s}$. G.M.T. The second was the larger, having a maximum ground amplitude of $43 \mu$ at Kew. Further moderately large earthquakes were registered at Kew on June 17,18 , and 22 , also on July 1 and 6 . Information is awaited from other observatories before details of these shocks can be given.

\section{Leverhulme Research Fellowships for I940}

THE trustees of the Leverhulme research fellowships have made awards tenable for varying periods up to two years, for research in the subjects indicated, to the following, among others: Prof. J. R. Bellerby, formerly Brunner professor of economic science, University of Liverpool, post-War economic reconstruction; Dr. R. M. Davies, lecturer in physics, University College, Aberystwyth, experimental investigations on turbulent flow in an air tunnel (renewal of present fellowship); Dr. A. G. Gaydon, Radiation Gas Research Fellow, Imperial College, London, a spectroscopic study of combustion processes in flames and explosions; Dr. N. A. V. Piercy, reader in aeronautics, University of London, mathematical theory of wing sections; W. $H$. Warburton, Fircroft College, Bournville, a survey of the North Staffordshire pottery industry.

\section{Announcements}

Mr. J. C. Crocker has been appointed head of the Department of Chemistry, Chelsea Polytechnic, London, following the retirement on August. 31 next of Mr. C. Dorée, who has held the post during the last sixteen years. Mr. Crocker has been senior lecturer on the staff of the Department of Chemistry for many years, during which time, in addition to taking his share in the preparation of a large number of students for their first degree in the University, he has done highly successful work in the training and direction of research students of the Polytechnic for the higher degree in chemistry of the University of London.

IT is announced by the Institution of Naval Architects that the Institution's Library has now been completed by the erection of the memorial to the late Sir Archibald Denny. The Library is situated at the offices of the Institution at 10 Upper Belgrave Street, London, S.W.I.

DR. Fred C. Koch, professor of physiological chemistry at the University of Chicago and chairman of the Department of Biochemistry, has been ap. pointed Frank P. Hixon distinguished service professor of chemistry in succession to Dr. Anton J. Carison, who will retire at the end of this year. 